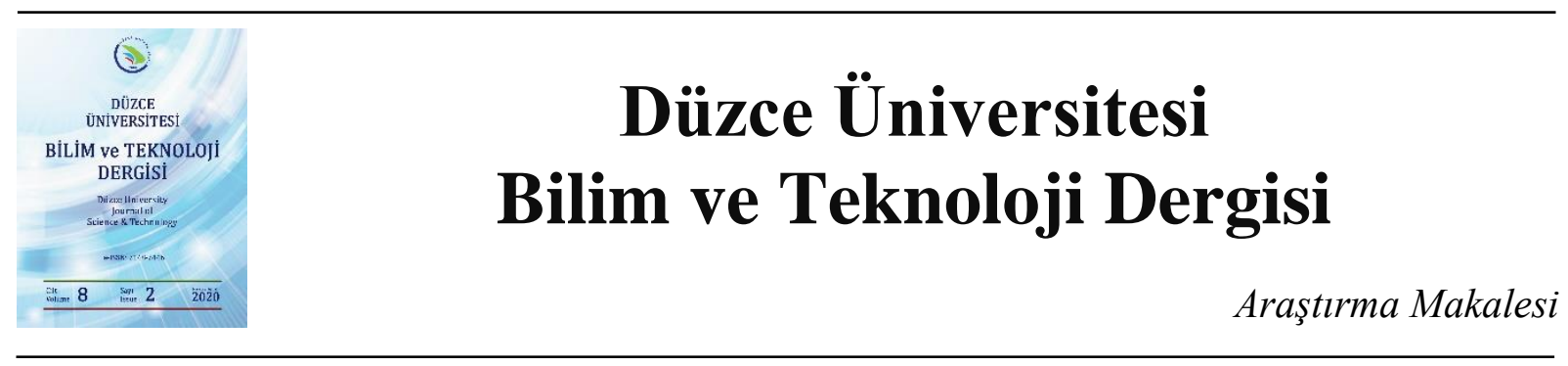

\title{
Düzce Merkez ve İlçelerinin Deprem Senaryolarına Göre Karşılaştırmalı Olarak İncelenmesi
}

\author{
Levent SABAH $^{\text {a,* }}$, iD Hüseyin BAYRAKTAR ${ }^{\text {b }}$ \\ ${ }^{a}$ Bilgi Işslem Daire Başkanlığg, Rektörlük, Düzce Üniversitesi, Düzce, TÜRKIYY \\ ${ }^{b}$ Yapı Ressamlığı Bölümü, Kaynaşlı MYO, Düzce Üniversitesi, Düzce, TÜRKIYE \\ * Sorumlu yazarın e-posta adresi: leventsabah@duzce.edu.tr \\ DOI : 10.29130/dubited.574013
}

\begin{abstract}
ÖZET
Depremin oluşumu ile ilgili ileriye dönük zamansal ve mekânsal tahmin edilmesi günümüz teknolojileri ile mümkün değildir. Fakat afete hazırlık aşamasında olası bir depremin etkilerini somutlaştırmak için oluşturulacak deprem senaryoları ile bir ilin güncel durumu belirlenebilir. Böylece şiddeti yüksek yani insanların can ve mal kayıplarının artabileceği bir deprem senaryosu kurgulanarak afete hazır olmak için gereken önlemlerin alınması sağlanabilir. Çalışmada çeşitli deprem senaryoları oluşturulmuştur. Bunun için 12 Kasım 1999 tarihinde meydana gelen 7.2 magnitud değerindeki deprem noktası baz alınmıştır. Deprem noktasının yakınında bulunan diri faylara $11 \mathrm{~km}$ 'lik tampon bölgeler oluşturulmuş ve ilçelerin bulundukları deprem şiddet bölgeleri tespit edilmiştir. Sonrasında Türkiye İstatistik Kurumundan (TÜİK) alınan 2018 ilçe nüfusları ve 3.4 olan hane halkı sayılarına göre bu şiddet bölgeleri kullanılarak ilçeler bazında ağır, orta, az hasarlı bina sayıları ve ölü, yaralı sayıları ile birlikte açıkta kalacak insan ve ihtiyaç duyulacak çadır sayıları tespit edilmiştir. Elde edilen sonuçlar nüfusa oranlandığında il genelinde toplam 96961 binanın 22002 adeti ağır, 10774 orta ve 1671 adeti az hasarlı olacağı tahmin edilmiştir. Ayrıca 5720 ölü ve 14387 yaralı olacağı öngörülmüştür. Bununla birlikte açıkta kalacak 131108 kişi için 32777 çadır gerekmektedir. Mevcut maddi imkanlar değerlendirilerek varsa eksikliklerin giderilmesi ile olası bir deprem sonrasında hızlı müdahale imkânı artabilecektir.
\end{abstract}

Anahtar Kelimeler: Deprem, Deprem Senaryosu, Düzce, Coğrafi Bilgi Sistemi, Açık Kaynak Kodlu Yazılımlar

\section{Comparative Analysis of Düzce Central and Districts According to Earthquake Scenarios}

\begin{abstract}
$\underline{\text { ABSTRACT }}$
Forward-looking temporal and spatial prediction about the occurrence of the earthquake is not possible with today's technologies. Current situation of a province can be determined due to the earthquake scenarios that will be created to embody the effects of a possible earthquake. Thus, an earthquake scenario in which people have increased their life and property losses, the necessary precautions to be prepared for the disaster can be obtained. Various earthquake scenarios were created in the study. For this purpose, the epicenter point of 7.2 magnitud dated November 12, 1999 was used. $11 \mathrm{~km}$ buffer zones were created to the active faults In the vicinity of the epicenter and the earthquake intensity zones where the districts were located were identified. 2018 district populations and households number which is 3.4 are taken from the Turkey Statistical Institute. Afterwards, the districts were classified as heavy, medium or less damaged by using these regions of intensity. In addition, according to the number of building classes, dead, wounded, exposed people and the number of tents to be needed has been identified. When the obtained results are compared with the population, it is estimated that a
\end{abstract}

Geliş: 07/06/2019, Düzeltme: 07/02/2020, Kabul: 20/04/2020 
total of 96961 buildings will be 22002 heavy, 10774 medium and 1671 less damaged in the province. It is also estimated that 5720 dead and 14387 injured. However, 32777 tents are required for 131108 people to be exposed. By evaluating the existing resources, the possibility of rapid intervention after an earthquake with the elimination of deficiencies can be increased.

Keywords: Earthquake, Earthquake Scenario, Düzce, Geographical Information System, Open Source Software

\section{GIRIS}

Deprem, doğası gereği, çok sayıda birbiriyle ilişkili ve karmaşık parametreler içerir ve kesin olarak tahmin edilmesi zordur [1]. Türkiye' de afetlerin neden olduğu can kaybı ve etkilenen yerleşim yerleri göz önüne alındığında depremlerin \%61' lik bir etkisi bulunmaktadır [2]. Alınan tüm önlemlerden bağımsız olarak kayıp ve kazaların tamamen önlenemeyeceği bazı durumlarda bile, acil durumların etkin bir şekilde ele alınması kurtarma operasyonlarına yardımcı olmak, ölüm ve yaralanma sayısını en aza indirmek için çok kritik hale gelebilmektedir. Bu nedenle, sismik risk yönetimi girişimleri için bir tahmin ve acil durum sistemi kurulmalıdır.

Son yıllarda insan kaynaklı veya doğal afetlerin artması afet yönetimini ilgi ve araştırmanın odak noktası haline getirmiştir [3]. Afet öncesi çalışmalar ile birlikte meydana gelebilecek afetlere karşı afet sırası ve sonrası için müdahale ve iyileşme süreçlerinin modellenmesi yapılmalıdır [4]. Deprem kaynaklı tehlikelerin varlığ yaşam alanlarının güvenliği için endişe yaratmaktadır. Ekonomik ve can kaybı gibi çeşitli sonuçları vardır. Bu nedenle, deprem afetine bağlı tehlike tahmin çalışmaları hayati öneme sahiptir [1].

İl ve ilçelerin deprem riski açısından incelenmesi üzerine çeşitli çalışmalar yapılmıştır. Analitik Hiyerarşi Süreci (Analytical Hierarchy Process - AHP) üzerine [5][6][7], Bulanık Mantık yöntemleri kullanılarak [8] elde edilen sonuçlar ile il ve ilçelerin genel olarak risk puanları ortaya çıkarılmıştır. Bu puanlar ile afet öncesi hazırlık aşamasında karar vericiler için ilçeler arasında önceliklendirme yapılabilmekte ve afet sonrasında can ve mal kaybının azaltılmasına yönelik çalışmalarda belirleyici olabilmektedir.

Bununla birlikte çeşitli yöntemler ile deprem senaryoları oluşturularak kayıp tahmin model çalışmaları da yapılmaktadır. Bu bağlamda Işık ve ark. çalışmalarında [9] Kırşehir ili için üç ayrı deprem senaryosu kurgulamışlardır. Her bir senaryoda bina hasar durumları, can ve mal kayıpları ile birlikte ekonomik kayıpları elde etmişlerdir. Karaağaç ve ark. [10] çalışmalarında Kahramanmaraş ve Adıyaman illeri için deprem senaryosu ile olası etki alanı belirlenmesi için AHP ve CBS (Coğrafi Bilgi Sistemleri) yöntemleri kullanmışlardır. Bölge heyelan, su baskını, kaya düşmesi ve çı̆̆ gibi afetler göz önünde bulundurularak; erişebilirlik, altyapı, topoğrafya, kapasite, arazi kullanım türü gibi kriterler belirlenmiş ve AHP yönteminde kullanılmıştır. CBS ile iller için en uygun yerleşim alanları belirlenmiştir. Karaman ve ark. [11] İstanbul ili için hasar görebilirliği ile birlikte mevcut yapının doğurabileceği sonuçlar üzerine çalışmışlardır. Bunun için AHP ve CBS ile geliştirdikleri karar destek sistemiyle beklenen İstanbul depremi sonrasında geçici barınma alanlarının yer seçimi sürecinin analizi yapılmıştır. Zülfikar ve ark. [12] ELER (Earthquake Loss Estimation Routine- Deprem Kayıp Tahmin Programı) yazılımı ile 1970 Gediz/Kütahya ve 2011 Simav/Kütahya depremlerinin gözlemsel bilgilerini kullanarak hasar kayıp tahmini üzerine simülasyon çalışmaları yapmışlardır. ELER, Avrupa Birliği NERIES (Network of Research Infrastructures for European Seismology) Projesi kapsamında, depremin toplum üzerindeki fiziksel, sosyal ve ekonomik sonuçlarının gösterilmesini kapsayan bir araştırma projesidir. ELER programının temel amacı, depremden etkilenen yerleşim yerlerini, buralardaki tahmini hasarlı bina, ölü ve yaralı sayısı, acil barınma ve beslenme ihtiyacı hakkında harita ve bilgi üretmektir [13]. Fahjan ve ark. [14] Gebze/Kocaeli ilçesi için risk yapısını deprem senaryoları 
ile değerlendirmişlerdir. Senaryolarında kırılması muhtemel üç fay seçilmiş ve bunlar üzerinde farklı büyüklüklerdeki depremler ile kırıldıkları kabul edilmiştir. Oluşturdukları senaryo depremler ile kırılması muhtemel fay hatlarının her biri için deprem şiddet eğrileri, olası kayıp ve hasar oranlarını çıkarmışlardır. Ayrıca mahalle bazında beklenen şiddet, hasar seviyeleri zemin etkisinin dikkate alındığı ve alınmadığı durumlar için harita üzerinde ayrı ayrı gösterilmiştir.

Depremden kaynaklanan bina hasarı, ağır can ve mal kayıplarının ana nedenidir. Binaların sismik kırılganlığı yalnızca sismik risk değerlendirmesi için değil, aynı zamanda deprem öncesi afet önleme ve deprem sonrası acil kurtarma emri ve eylemleri için de çok önemli olan deprem afet kayıplarının hızlı bir şekilde değerlendirilmesi için önemli bir başlangıç noktasıdır [15].

Afet sonrasında müdahale aşamasında yaralı insanların tahliye ve barındırılmaları için toplanma ve çadır alanlarının belirlenmesi önemlidir [16]. Çadır alanlarının uygun yer seçimleri için afet sonrası ihtiyaç duyulabilecek çadır sayısının belirlenmesi ile birlikte coğrafi bilgi sistemleri kullanılarak ilçeler bazında uygun alanlar belirlenebilmektedir. Yine ciddi yaralanma durumlarında kişilerin en uygun hangi hastanelere transfer edileceğinin belirlenmesi de hızlı müdahale için önemlidir.

\section{MATERYAL ve YÖNTEM}

Bu çalışmada 2 farklı şekilde deprem senaryosu uygulanmıştır. Bunlardan ilki Özmen'in geliştirdiği [17] yöntemde kullanılan nüfus verilerinden bina sayılarının elde edilmesi ve sonrasında da senaryoda kullanılacak verilerin formülize edilmesi ile yapılmıştır. İkincisi ise Düzce Belediyesi İmar ve Şehircilik Müdürlüğ̈̈/Kent Bilgi Sistemi’nden temin edilen Düzce merkez ilçesine ait binaların kapalı alan (poligon) mekânsal verilerinin Coğrafi Bilgi Sistemi (CBS) kullanılarak oluşturulan deprem şiddet bölgeleri ile kesiştirilmesi sonucunda elde edilen bina sayıları baz alınarak merkez ve ilçeler için yapılan senaryodur.

\section{A. KONUMSAL VERILERIN ELDE EDILLMESI}

Deprem senaryosunda konumsal verilerin elde edilmesinde Açık Kaynak Kodlu Coğrafi Bilgi Sistemi olan QGIS [18] ile Düzce ili ilçe sınırları altlık olarak Bing Maps [19] kullanılarak, diri faylar ise MTA Yerbilimleri Harita Görüntüleyici ve Çizim Editörü [20] altlık kullanılarak oluşturulmuştur (Şekil 1).

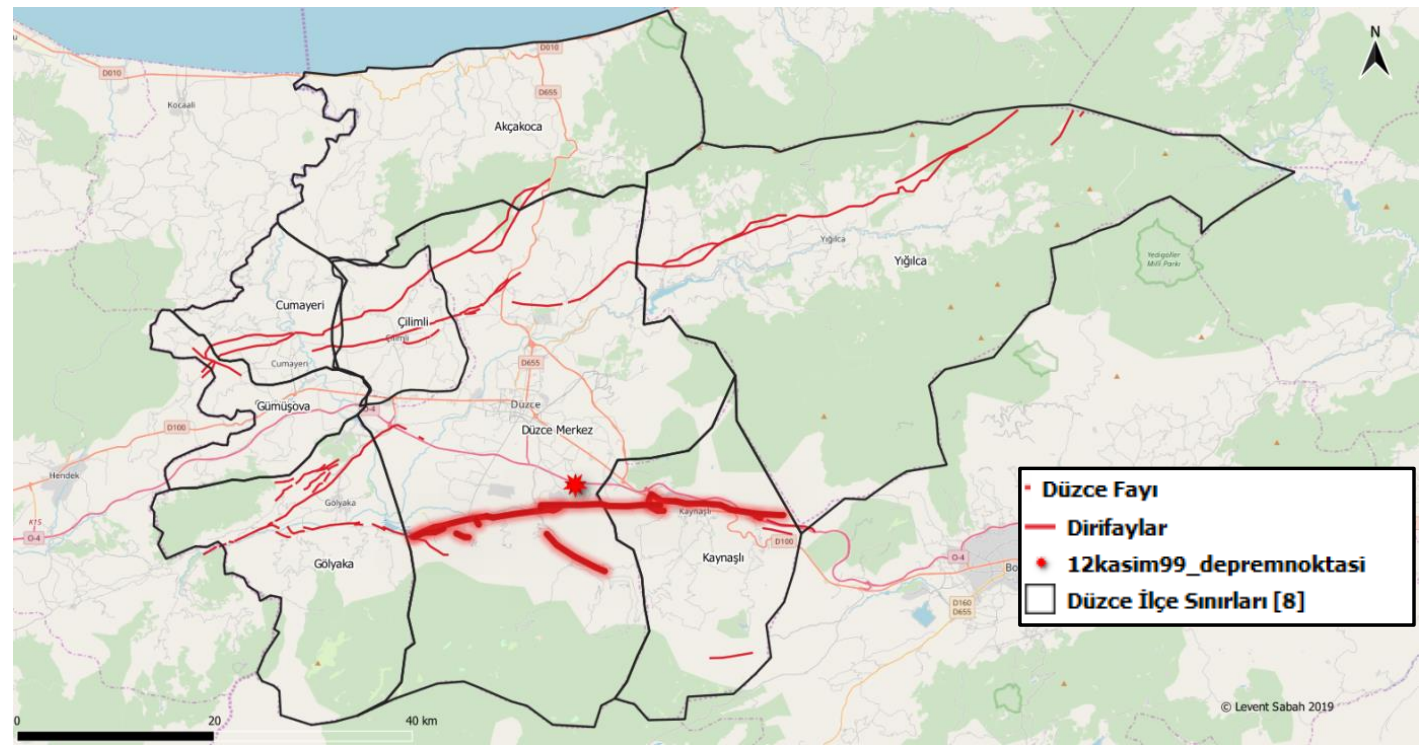

Şekil 1. Düzce ili ilçe sınırları ve diri faylar. 
Deprem şiddetinin etkilerinin, depremin oluştuğu bölgeden uzaklaştıkça azaldığı aşikardır. Deprem şiddeti, depremin oluşturduğu gözlenen etkilere göre hazırlanan çeşitli şiddet cetvelleri ile belirlenmektedir [17]. Türkiye' de kullanılan şiddet cetveli oniki dereceli Medvedeev-SponhuverKarnik (MSK) 'dır [21]. Depremlerin şiddet ve magnitüd değerleri arasında çıkarılan ampirik bağıntılara göre [22] 7.2'lik magnitüd için X şiddet değeri üst sınır olarak belirlenmiştir. Diri faylardan Düzce Fay1 seçilerek etrafında 11 km'lik 5 adet tampon bölge oluşturulmuştur (Şekil 2). Diri faylardan başlayarak her bir tampon bölge VI- X arası şiddet bölgesi olarak tanımlanmıştır.

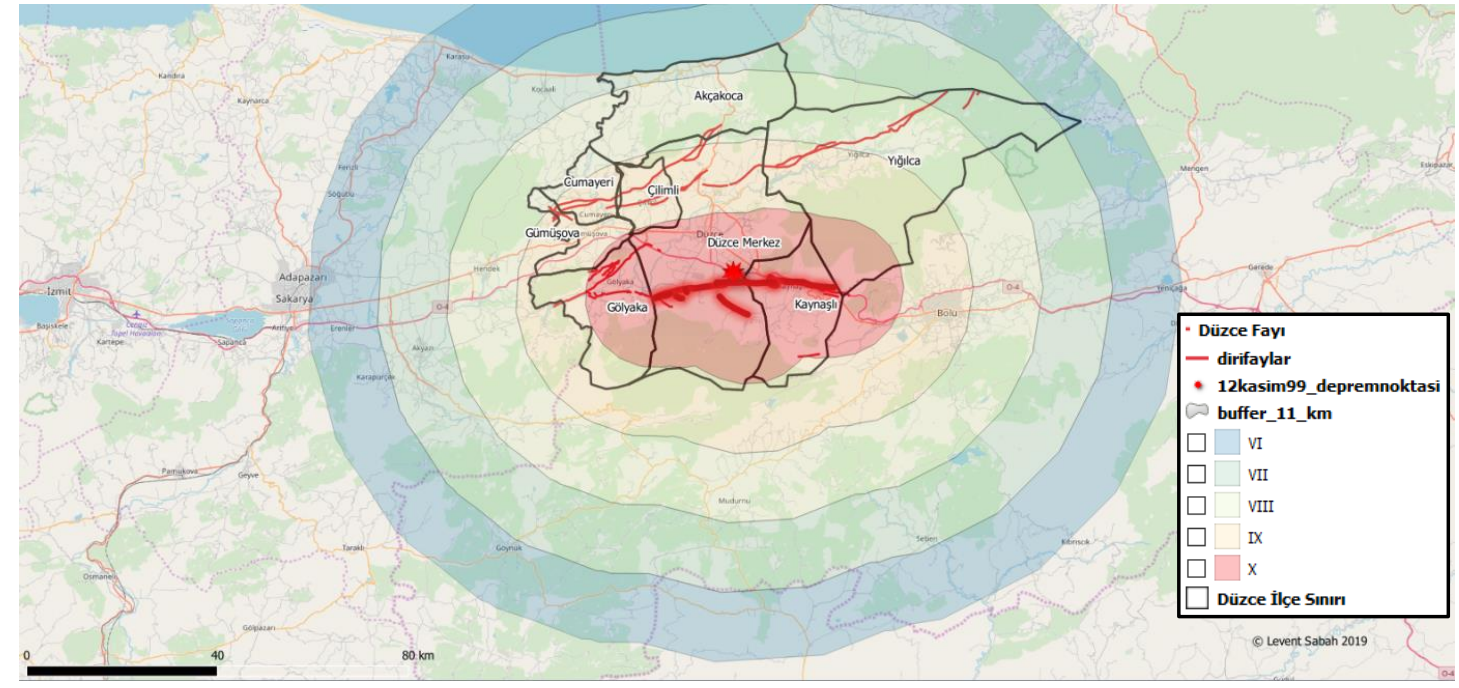

Şekil 2. Düzce fayı baz alınarak oluşturulan $11 \mathrm{~km}$ 'lik X-VI aralı̆̆ında deprem şiddetinde tanımlanan tampon bölgeler.

Senaryoda deprem şiddet bölgelerinin elde edilmesi için AFAD web sayfasından [23] 12 Kasım 1999 Düzce depreminin meydana geldiği 40.7900 (K), 31.2100 (D) koordinat1 yakınında bulunan Düzce fayı baz alınarak tampon bölgeler oluşturulmuştur. Bu tampon bölgeler Düzce Belediyesi İmar ve Şehircilik Müdürlügü̈/Kent Bilgi Sistemi'nden temin edilen kapalı alan formatındaki merkez ilçelere ait binalar ile mekânsal kesişim analizi yapılmıştır. Analiz sonucunda IX. ve X. Deprem şiddet bölgelerinde bulunan bina sayıları senaryoda kullanılmıştır.

\section{B. SAYISAL VERILERIN OLUŞTURULMASI}

Deprem senaryosunda elde edilecek sonuçların dayanağı olan Türkiye İstatistik Kurumu (TÜIK)'ndan elde edilen 2018 y1lına ait nüfus verileri [24] ve hane halkı büyüklüklerinin [25] Tablo 1'de [17] gösterilen katsayılar ile birlikte kullanımıyla ilçeler bazında konut sayıları, konutların bulundukları deprem şiddet bölgesine göre ağır, orta ve az hasarlı olma durumları hesaplanmaktadır. Ayrıca ölü ve yaralı sayıları ile birlikte açıkta kalacak insan sayısı ve ihtiyaç duyulacak çadır sayıları da benzer şekilde hesaplanmaktadır.

Tablo 1' deki katsayılar Özmen'in [17] çalışmasında 17 Ağustos 1999 İzmit Körfezi Depreminden farklı şiddetlerde etkilenmiş bölgelerdeki hasar oranlarından elde edilmiştir. Örnek olarak VIII şiddet bölgesinde bulunan konutların \%2,82'sinin ağır ve yıkık hasar, $\% 4,41$ 'inin orta hasar ve $\% 5,31$ 'inin az hasar alabileceği çıkarımı yapılabilir. 17 Ağustos 1999 tarihinde 73km'lik fayın 30km'lik batı bölümü kırıldıktan sonra 12 Kasım 1999 tarihindeki depremde ise fayın 43 km'lik doğu bölümünün kırılmasından dolayı çalışmamızda Düzce ili içinde aynı katsayılar kullanılmıştır [26]. 
Tablo 1. Deprem şiddet bölgelerin hesaplanmasında kullanılan katsayılar.

\begin{tabular}{cccc}
\hline Şiddet Bölgesi & Ă̆ır ve Yıkık Hasar & Orta Hasar & Az Hasar \\
\hline VI & 0,04 & 0,22 & 0,24 \\
\hline VII & 0,91 & 2,67 & 2,59 \\
\hline VIII & 2,82 & 4,41 & 5,31 \\
\hline IX & 15,70 & 18,16 & 22,75 \\
\hline X & 33,06 & 15,29 & 19,14 \\
\hline
\end{tabular}

Burada Konut sayısı (Eşitlik 1), Ağır Hasarlı Bina sayısı (Eşitlik 2), Orta Hasarlı Bina sayısı (Eşitlik 2), Az Hasarlı Bina sayısı (Eşitlik 2), Ölü Sayısı (Eşitlik 3), Yaralı Sayısı (Eşitlik 4), Açıkta Kalacak İnsan Sayısı (Eşitlik 5), Çadır İhtiyacı (Eşitlik 6) aşağıdaki eşitlikler ile hesaplanmaktadır. Burada $\eta$, İlçe nüfusu; $\beta$, İlin Ortalama Hane Halkı Büyüklügü̈; $\alpha=3.4$, Tablo 1' deki katsayıları temsil etmektedir. Eşitlik 3' de kullanılan 0.26 değeri 17 Ağustos 1999 İzmit Körfezi depremindeki ölü sayısının ağır hasarlı konut sayısına bölünmesi ile elde edilen katsayıdır [17]. Eşitlik 4' de kullanılan 2.515 değeri ise yine aynı depremdeki yaralı sayısının ölü sayısının kaç katı olduğunun hesaplanması ile elde edilmiştir [17].

Konut Sayısı $=\eta / \beta$

Hasarlı Bina Sayısı $=(\alpha * \eta) / 100$

Ölü Sayısı = Ağır Hasarlı Bina Sayısı $* 0,26$

Yaralı Sayısı $=$ Ölü Sayısı $* 2,515$

Açıkta Kalacak İnsan Sayısı $=($ A ̆ğ ve Orta Hasarlı Bina Sayısı Toplamı $) * \beta$

İhtiyaç Duyulacak Çadır Sayısı = Açıkta Kalacak İnsan Sayısı $/ \beta$

Eşitlik 1-6 kullanımı ile Tablo 2 elde edilmiştir.

Tablo 2. Elde edilen bulgulara göre Düzce merkez ve ilçelere ait deprem senaryosu sonuçları.

\begin{tabular}{|c|c|c|c|c|c|c|c|c|c|c|}
\hline \multirow[b]{2}{*}{ İlçe } & \multirow[b]{2}{*}{ Şiddet } & \multirow[b]{2}{*}{ Nüfus } & \multirow{2}{*}{$\begin{array}{l}\text { Konut } \\
\text { Sayısı }\end{array}$} & \multicolumn{3}{|c|}{ Bina Hasar Durumu } & \multirow[b]{2}{*}{ Ölü } & \multirow[b]{2}{*}{ Yaralı } & \multirow{2}{*}{$\begin{array}{c}\text { Açıkta } \\
\text { Kalacak } \\
\text { İnsan } \\
\text { Sayısı } \\
\end{array}$} & \multirow{2}{*}{$\begin{array}{c}\text { Çadır } \\
\text { İhtiyacı }\end{array}$} \\
\hline & & & & A & Orta & $\mathbf{A z}$ & & & & \\
\hline Akçakoca & VIII & 38846 & 11425 & 322 & 504 & 607 & 84 & 211 & 2809 & 826 \\
\hline Çilimli & IX & 20266 & 5961 & 936 & 1082 & 1356 & 243 & 612 & 6862 & 2018 \\
\hline Cumayeri & IX & 14895 & 4381 & 688 & 796 & 997 & 179 & 450 & 5043 & 1483 \\
\hline Gölyaka & $\mathrm{X}$ & 20353 & 5986 & 1979 & 915 & 1146 & 515 & 1294 & 9841 & 2894 \\
\hline Gümüşova & IX & 15647 & 4602 & 723 & 836 & 1047 & 188 & 472 & 5298 & 1558 \\
\hline Kaynaşlı & $\mathrm{X}$ & 20772 & 6109 & 2020 & 934 & 1169 & 525 & 1321 & 10043 & 2954 \\
\hline Merkez & $X$ & 240633 & 70774 & 23398 & 10821 & 13546 & 6083 & 15300 & 116346 & 34219 \\
\hline Yiğılca & IX & 16432 & 4833 & 759 & 878 & 1099 & 197 & 496 & 5564 & 1636 \\
\hline
\end{tabular}

\section{C. İLK DEPREM SENARYOSUNUN KURGULANMASI}

Öncelikli olarak deprem senaryosu oluşturulurken her ilçenin içinde bulunduğu deprem şiddet bölgesi coğrafi bilgi sistemi kullanılarak oluşturulmuştur. Bunun için meydana gelmiş ya da kurgulanan bir epicenter ve büyüklüğü tanımlanır. Bu çalışmada 12 Kasım 1999 tarihinde meydana gelen 7.2 
büyüklügündeki Düzce depremi üzerine deprem senaryosu kurgulanmıştır. Daha sonrasında seçilen epicenter civarında bulunan diri faylar üzerinde tampon bölge analizi yapılır. Çalışmamızda seçtiğimiz epicenter civarında bulunan Düzce fayı kullanılmıştır. Bu fay etrafında $11 \mathrm{~km}$ 'lik tampon bölgeler oluşturularak hangi ilçenin hangi tampon bölge diğer bir deyişle hangi deprem şiddet bölgesinde kaldığ tespit edilmiştir. İlçelerin hangi deprem şiddet bölgesinde olduğunun tespiti için ise ilçe sınırları ile deprem şiddet bölgeleri tampon bölge katmanları ile kesişim analizi yapılmıştır. Analiz sonucunda ilçelerin deprem şiddet bölgelerinde kalan alanlarının yüzdeleri hesaplanarak hangi deprem şiddet bölgesinde daha fazla alanı var ise ilçe o bölgeye atanmıştır (Tablo 3).

Tablo 3. Düzce merkez ve ilçelerin deprem şiddet bölgelerindeki en fazla bulundukları alan yüzdeleri.

\begin{tabular}{cccccc}
\hline İlçe & $\begin{array}{c}\text { Deprem } \\
\text { Şiddet } \\
\text { Bölgesi }\end{array}$ & $\begin{array}{c}\text { Kapladığı } \\
\text { Alan (\%) }\end{array}$ & İçe & $\begin{array}{c}\text { Deprem } \\
\text { Şiddet } \\
\text { Bölgesi }\end{array}$ & $\begin{array}{c}\text { Kapladığı } \\
\text { Alan (\%) }\end{array}$ \\
\hline Akçakoca & VIII & 79,06 & Gölyaka & X & 60,03 \\
\hline Cumayeri & IX & 68,92 & Gümüşova & IX & 82,62 \\
\hline Çilimli & IX & 93,96 & Kaynaşlı & X & 93,17 \\
\hline Merkez & $\mathrm{X}$ & 61,89 & Yığılca & IX & 35,88 \\
\hline
\end{tabular}

Deprem senaryosu uygulanacak yerleşim ile ilgili kesin bina sayıları olmaması durumunda Özmen'in [17] çalışmasında kullanılan yöntemde nüfus sayısının hane halkı büyüklüğü olan 3.4 değerine bölünmesi ile bina sayıları elde edilmiştir (Eşitlik 1). Bina sayıları elde edildikten sonra Eşitlik 2' de belirtildiği gibi konut sayıları ağır, orta ve az hasarlı olmak üzere hesaplamaları yapılmıştır. Daha sonra Tablo 1' deki katsayılar ve deprem şiddet bölgelerine göre ağır, orta ve az hasarlı bina sayıları elde edilmiştir. Eşitlik 3 kullanılarak ağır hasarlı bina sayısından ölü sayısı ve Eşitlik 4 de ise ölü sayısından yaralı sayısı hesaplanmaktadır. Eşitlik 5 de ağır ve orta hasarlı bina sayısı toplamından açıkta kalacak insan sayısı, sonrasında ise açıkta kalacak insan sayısına göre ihtiyaç duyulacak çadır sayıları elde edilmiştir.

\section{D. İKİNCI DEPREM SENARYOSUNUN KURGULANMASI}

İkinci deprem senaryosunda ise Özmen'in [17] çalışmasından farklı olarak Düzce Belediyesi İmar ve Şehircilik Müdürlüğ̈̈/Kent Bilgi Sistemi’nden temin edilen Düzce merkez ilçesine ait binaların kapalı alan (poligon) mekânsal verileri kullanılarak binaların harita üzerinde hangi deprem şiddet bölgesine girdiği daha net görülebilmektedir (Şekil 3). QGIS ile oluşturulan deprem şiddet bölgeleri katmanı ile temin edilen bina verileri katmanı kesiştirilerek IX. bölgede 4608 ve X. bölgede 25999 adet bina olduğu görülmüştür. Temin edilen 30593 veriden kesişim sonucunda toplamda 30607 bina verisi elde edilmiştir. Bunun nedeni tampon bölge sınırlarında olan binaların 2 kere hesaplanmasıdır. 


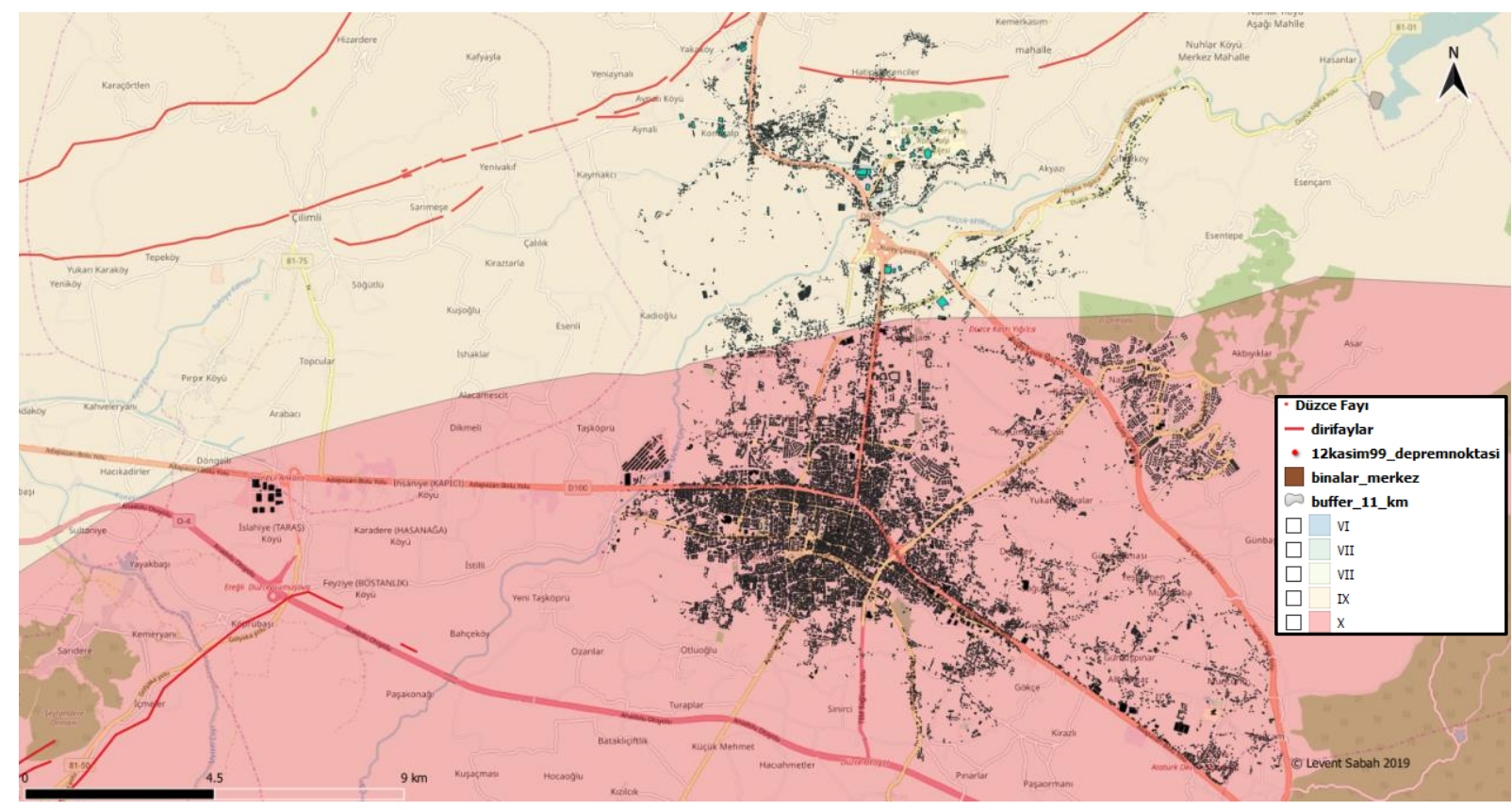

Şekil 3. Merkez ilçe bina verilerinin gösterimi.

Doğrudan bina verileri kullanılarak kurgulanan ikinci senaryoda elde edilen sonuçlar merkez ilçenin IX. ve X. deprem şiddet bölgelerine denk düşen bina sayıları ile hesaplanmıştır (Şekil 4). Tablo 4'de ilk senaryoda merkez ilçe için elde edilen sonuçlar ile birlikte ikinci senaryoda merkez ilçenin IX. ve $\mathrm{X}$. deprem şiddet bölgesinde bulunan bina sayılarında elde edilen sonuçlar gösterilmektedir.

Tablo 4. Merkez ilçe için kurgulanan iki deprem senaryosunun sonuçları.

\begin{tabular}{|c|c|c|c|c|c|c|c|c|c|c|}
\hline \multirow[b]{2}{*}{ Senaryolar } & \multirow[b]{2}{*}{ İlçe } & \multirow[b]{2}{*}{ Şiddet } & \multirow[b]{2}{*}{$\begin{array}{l}\text { Konut } \\
\text { Sayısı }\end{array}$} & \multicolumn{3}{|c|}{ Bina Hasar Durumu } & \multirow[b]{2}{*}{ Ölü } & \multirow[b]{2}{*}{ Yaralı } & \multirow{2}{*}{$\begin{array}{c}\text { Açıkta } \\
\text { Kalacak } \\
\text { İnsan } \\
\text { Sayısı }\end{array}$} & \multirow[b]{2}{*}{$\begin{array}{c}\text { Çadır } \\
\text { İhtiyacı }\end{array}$} \\
\hline & & & & Ăğır & Orta & $\mathbf{A z}$ & & & & \\
\hline $\begin{array}{c}\text { Birinci } \\
\text { Senaryo }\end{array}$ & Merkez & $\mathrm{X}$ & 70774 & 23398 & 10821 & 13546 & 6083 & 15300 & 116346 & 34219 \\
\hline \multirow{2}{*}{$\begin{array}{l}\text { İkinci } \\
\text { Senaryo }\end{array}$} & Merkez IX & IX & 4608 & 723 & 837 & 1048 & 188 & 473 & 5305 & 1560 \\
\hline & Merkez X & $\mathrm{X}$ & 25999 & 8595 & 3975 & 4976 & 2235 & 5620 & 42740 & 12571 \\
\hline
\end{tabular}




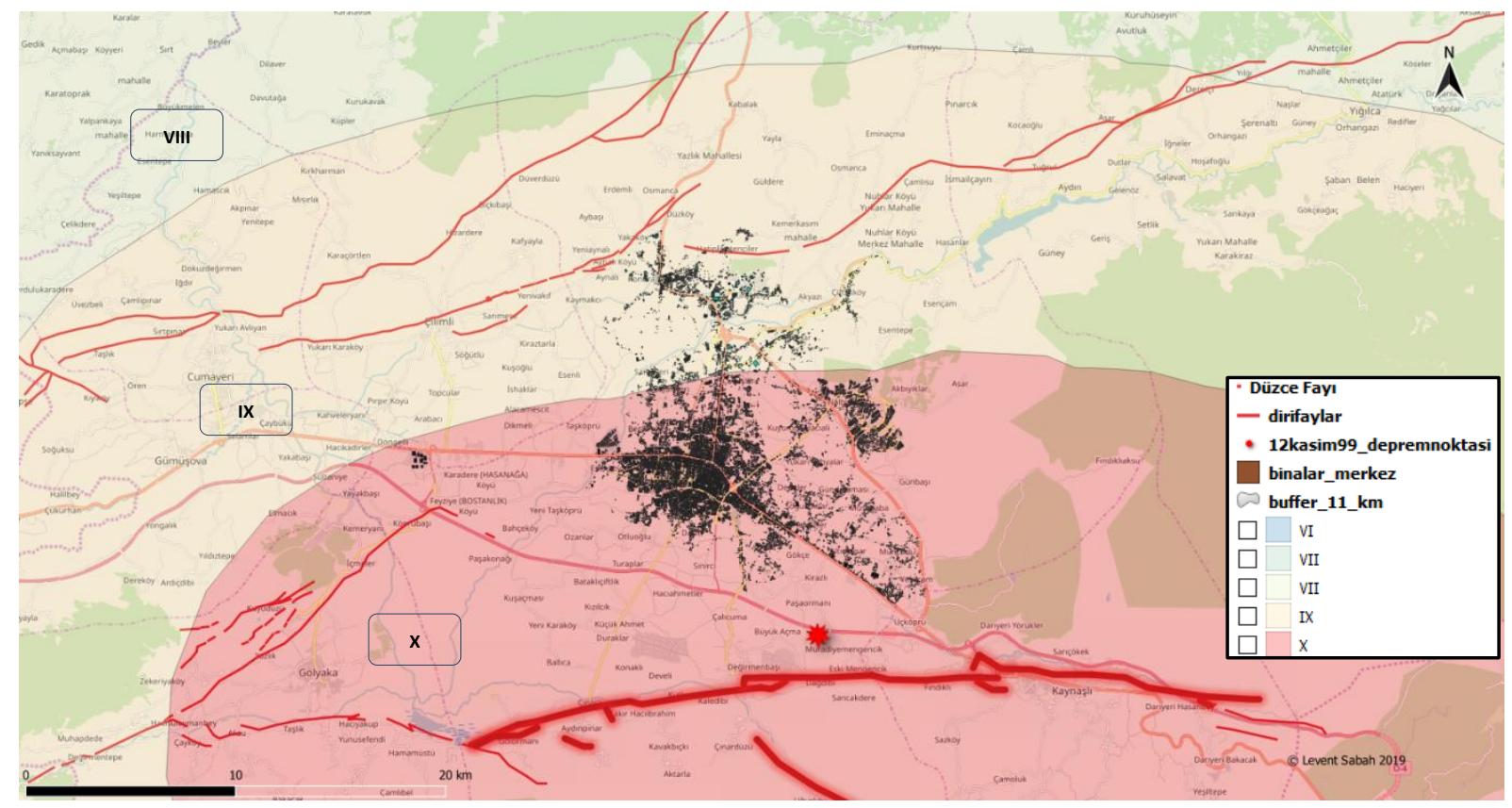

Şekil 4. Merkez ilçe bina verilerinin diri faylar, 12 Kasım 1999 Düzce epicenteri ve deprem şiddet bölgeleri ile birlikte gösterimi.

\section{SONUCLAR ve TARTISSMA}

Afetler meydana gelmeden önce yapılacak çalışmalar can ve mal kaybının azaltılması için önem teşkil etmektedir. Depremin engellenemeyecek bir afet olmasından dolayı meydana geldiğinde mümkün olan en az zararla deprem sırası ve sonrası sürecinin atlatılması için hazırlıklı olmak önemlidir. Kurgulanacak deprem senaryoları ile afet sonrasında alınacak aksiyonlar ilçeler bazında belirlenebilir. Deprem riski yüksek olan ilçe ya da yerleşimlere öncelik verilerek olası can ve mal kayıplarının azaltılması çalışmalarında belirleyici rol alabilmektedir.

Çalışmada iki farklı deprem senaryosu uygulanmıştır. Bunlardan ilkinde ilçeler $11 \mathrm{~km}$ 'lik tampon bölgeler şeklinde oluşturulan deprem şiddet bölgelerinde bulundukları alanlara göre şiddet bölgelerine atanmıştır. Alan olarak hangi bölgede daha çok yer kapliyor ise o deprem şiddet bölgesine atanan ilçeler için Özmen (2002)'in çalışmasında belirtilen Eşitlik 1'den 6'ya kadar ilçelerin TÜİK'den alınan 2018 nüfus ve hane halkı sayıları kullanılarak uygulanmış ve Tablo 2' deki değerler elde edilmiştir. Elde edilen sonuçlara göre merkez ilçe hem nüfus olarak diğer ilçelerden fazla olması hem de deprem şiddet bölgesi olarak tanımlanan en yüksek bölge olan X' de değerlendirildiği için bina hasarları, ölü, yaralı, açıkta kalacak insan sayıları ve çadır ihtiyacı en çok olan ilçedir. X bölgesinde olan diğer ilçeler ise Kaynaşlı ve Gölyaka'dır. Düzce ili için en düşük deprem şiddet bölgesi olan VIII. Bölgede Akçakoca ilçesi bulunmaktadır. Diğer ilçeler Çilimli, Cumayeri, Gümüşova ve Yığılca ise IX. bölgededir.

Düzce ilçelerinin AHP ve Bulanık Mantık yöntemleri ile deprem tehlike analizini yaptığımız diğer bir çalışmamızda [8] elde ettiğimiz tehlike değerlerine göre yapılan ilçe sıralamalarında yine Merkez ilçe, diğer ilçelere göre en yüksek tehlike değerini almaktadır. Sırasıyla Yığılca, Gölyaka ve Kaynaşlı ilçeleri orta dereceli riskli ilçeler ve sırasıyla Çilimli, Gümüşova, Cumayeri ve Akçakoca ilçeleri en az riskli ilçeler olarak elde edilmiştir. Klasik AHP ve/veya Bulanık Mantık gibi yöntemlerle yapılan çalışmalarda karar verici / değerlendirme yapan uzmanın tecrübesine/ yorumlamasına göre sonuçlar elde edilmektedir. Eldeki verilerle geleceğe dönük hızlı bir model oluşturulup tahmin yapılmasından dolayı afet öncesinde yapılacak planlamalarda, afet sırası ve sonrasında izlenecek strateji ve planların oluşturulması açısından önemlidir. Bunun yanında bu çalışmamızda formülize edilen deprem 
senaryoları ile ilçelerin bulundukları deprem şiddet bölgelerine göre daha somut bilgiler elde edilebilmektedir. Ayrıca önceki çalı̧̧mamızda [8] Düzce ilinin deprem riskini ele alırken ilçelerin sahip olduğu doğal ve insanoğlunun oluşumunda / değişiminde etkisinin neredeyse olmadığı diri fay uzunluğu, deprem epicenter büyüklükleri ve alüvyon alanların değerlerine göre değerlendirme yapılarak mevcut durum ortaya konulmuştur. Bu çalışmamızda ise ilçeler, tanımlandıkları şiddet bölgelerine göre konut ve nüfusları ile direkt olarak bir deprem sonrasında etkilenebilecek insanların/ binaların sayıları formülize edilebilmektedir. Yine karar vericiler için elde edilen somut bilgiler ile ilçelerin sahip oldukları mevcut imkanlarla yapılacak çıkarımlar sayesinde planlamalar yapılabilir.

İkinci deprem senaryosunda ise merkez ilçede kapalı alan şeklinde bulunan sayısal bina verileri kullanılmıştır. Ayrıca merkez ilçe deprem şiddet bölgeleri ile kesişim analizi yapıldığında IX ve X bölgeleri olarak ikiye ayrılmaktadır. Binalar bulundukları deprem şiddet bölgesine göre ayrı ayrı değerlendirilmiş ve Eşitlik 1'den 6'ya kadar bu bina sayılarına uygulandığında

Tablo 4' de ilk deprem senaryosu ile birlikte ikinci deprem senaryosunun değerleri gösterilmektedir.

$\mathrm{Bu}$ çalışmada kurgulanan senaryolar ile Düzce merkez ve ilçelerinde olası bir deprem sonrasında oluşabilecek durum tespit edilmeye çalışılmıştır. Afet öncesi hazırlık aşamasında potansiyel risk ve elde bulunan imkanlar değerlendirilip erken aksiyonlar alınarak, oluşabilecek bir deprem sonrasında mümkün olan en az can ve mal kaybı hedeflenebilir. İkinci senaryoda kullanılan bina verilerinin temini ile anlık olarak güncel durumun tespiti yapılabilir. Burada bina verilerine ek olarak ilde bulunan diğer kurum ve paydaşlarla oluşturulacak bir afet bilgi yönetim sistemi ile afet öncesi ildeki mevcut bina envanteri, yol envanteri, sağlı personel sayıları, barınma ihtiyacının karşılanabileceği spor salonu, yurt, okul, otel, pansiyon sayıları, eczane, hastane, toplum sağlığı merkezleri gibi bina ve personellerin güncel sayıları ve kapasite gibi durumlarının tutulmasıyla birlikte afet sonrasında yol envanteri ile yol ağı analizleri yapılabilir. Böylece yıkıma uğrayan ya da uğramayan binalara göre alternatif güzergahlar belirlenerek en hızlı şekilde insanların sağlık kuruluşlarına sevki sağlanabilir.

TESSEKKÜR: Düzce merkez ilçeye ait bina verilerinin temini konusunda gösterdikleri ilgi ve destek için Düzce Belediyesi İmar ve Şehircilik Müdürlüğüne çok teşekkür ederiz.

\section{KAYNAKLAR}

[1] J. Wang, H. Gao, and J. Xin, "Development and Application of a GIS-based System for City Earthquake-Induced Hazard Estimate," 2010 Int. Conf. Intell. Comput. Technol. Autom. ICICTA 2010, c. 2 , ss. $82-85,2010$.

[2] A. S. Esin, T. Oğuzhan, K. C. Kaya, T. Ergüder, A. T. Özkan, ve İ. Yüksel, “Afetlerde Sağlık Hizmetleri Yönetimi,” Ankara, 2001.

[3] S. A. Bagloee, K. H. Johansson, ve M. Asadi, "A Hybrid Machine-Learning and Optimization Method for Contraflow Design in Post-Disaster Cases and Traffic Management Scenarios," Expert Syst. Appl., c. 124, ss. 67-81, 2019.

[4] E. M. Hassan ve H. Mahmoud, "Full Functionality and Recovery Assessment Framework for A Hospital Subjected to A Scenario Earthquake Event," Eng. Struct., c. 188, s. December 2017, ss. 165-177, 2019.

[5] C. Yalçın ve L. Sabah, "Açık Kaynak Kodlu CBS ve Analitik Hiyerarşi Proses (AHP) Yöntemi Kullanılarak Edirne Sanayi İşletmelerinin Deprem Tehlike Analizi,” Düzce Üniversitesi Bilim ve Teknoloji Dergisi, c. 5, s. 2, ss. 524-537, 2017.

[6] C. Yalçın ve L. Sabah, "Analitik Hiyerarşi Süreci (AHP) Kullanılarak Burdur'un Deprem Tehlike Analizinin Oluşturulması," in 17. Ulusal Bölge Bilimi ve Bölge Planlama Kongresi, 2017. 
[7] C. Yalçın ve L. Sabah, "Çanakkale Sanayi İşletmelerinin Deprem Tehlikesi Analizi," in 17. Ulusal Bölge Bilimi ve Bölge Planlama Kongresi, 2017.

[8] L. Sabah ve İ. Yücedağ, "Düzce İlçelerinin Ahp ve Bulanık Mantık Yöntemleri ile Deprem Tehlike Analizi," in Uluslararası Mühendislik Araştırmaları Sempozyumu 2017, 2017.

[9] E. Işık, Ç. Sağıroğlu, Z. Tozlu, ve Ü. S. Ustaoğlu, "Farklı Deprem Senaryolarına Göre Kırşehir İli Kayıp Tahmin Analizleri,” Doğal Afetler ve Çevre Derg., c. 90, s. 434, ss. 80-93, 2018.

[10] D. Karaağaç, H. Karaman, ve B. Aktuğ, "Kahramanmaraş ve Adiyaman İllerinin Afetselliğinin İncelenmesi ve Mekansal Analiz Teknikleriyle Yerleşime Uygun Alanların Belirlenmesi," Türk Deprem Araştırma Derg., c. 1, s. 2, ss. 123-133, 2019.

[11] H. Karaman, S. Rezaei, K. Kalkan, B. E. Konukçu, ve T. Erden, "Afet Sonrası En Uygun Geçici Barınma Alanlarının CBS ile Tespiti,” in 5. Uzaktan Algllama-CBS Sempozyumu, 2014.

[12] Ö. Zülfikar, C. Zülfikar, ve H. Alçık, "ELER Yazılımı ile Deprem Şiddeti, Hasar ve Kayıp Tahmini," in 1. Yerbilimleri Sempozyumu, 2012.

[13] T. C. Çevre ve Şehircilik Bakanlığı, "Eler (Deprem Kayıp Tahmin Programı)," 2017.

[14] Y. Fahjan, F. Pakdamar, Y. Eryılmaz, ve F. İ. Kara, "Afet Planlamasında Deprem Riski Belirsizliklerinin Değerlendirilmesi," Artvin Çoruh Üniversitesi Doğal Afetler ve Çevre Dergisi, c. 1, s. 1-2, ss. 21-39, 2015.

[15] X. Wang, A. Dou, X. Ding, ve X. Yuan, "Study on RS and GIS Based Comprehensive Analysis of Multi-Factors Affecting the Earthquake Risk: An Application of Monte Carlo Simulation," Int. Geosci. Remote Sens. Symp., ss. 3117-3120, 2014.

[16] P. Ghasemi, K. Khalili-Damghani, A. Hafezolkotob, ve S. Raissi, "Uncertain Multi-Objective Multi-Commodity Multi-Period Multi-Vehicle Location-Allocation Model for Earthquake Evacuation Planning," Appl. Math. Comput., c. 350, ss. 105-132, 2019.

[17] B. Özmen, "İstanbul İli İçin Deprem Senaryosu," TMH - Türkiye Mühendislik Haberleri, vol. 417, no. 2002/1, pp. 23-28, 2002.

[18] "QGIS." [Çevrimiçi]. Erişim Adresi: https://www.qgis.org/en/site/about. Erişim Tarihi: 17.07.2017.

[19] "Microsoft ${ }^{\circledR}$ BingTM Maps Platform API." [Çevrimiçi]. Erişim Tarihi: https://www.bing.com/maps. Erişim Tarihi: 22.05.2019.

[20] "MTA Yerbilimleri Harita Görüntüleyici ve Çizim Editörü.” [Çevrimiçi]. Erişim Adresi: http://yerbilimleri.mta.gov.tr/anasayfa.aspx. Erişim Tarihi: 22.05.2019.

[21] "Medvedev-Sponheuer-Karnik scale." [Çevrimiçi]. Erişim Adresi: http://www.tal.univparis3.fr/plurital/travaux-2007-2008/L7T04-2007-2008/DUPLAT_mathieu-

Mohamed_TOURE/PAGESASPIREES/anglais/scale/11.html. Erişim Tarihi: 22.05.2019.

[22] M. Tamer ÖZMEN, Deprem ve Antalya'nın Depremselliği. TMMOB İnşaat Mühendisleri Odas1, 2007.

[23] "AFAD Deprem Dairesi Başkanlığı." [Çevrimiçi]. Erişim Adresi: https://deprem.afad.gov.tr/depremdetay?eventID=246572. Erişim Tarihi: 22.05.2019. 
[24] TÜiK, “Adrese Dayalı Nüfus Kayıt Sistemi Sonuçları.” [Çevrimiçi]. Erişim Adresi: https://biruni.tuik.gov.tr/medas/?kn=95\&locale=tr. Erişim Tarihi: 22.05.2019.

[25] TÜİK, "İllere göre ortalama hanehalkı büyüklüğü, 2008-2018.” [Çevrimiçi]. Erişim Adresi: http://www.tuik.gov.tr/PreIstatistikTablo.do?istab_id=2308. Erişim Tarihi: 22.05.2019.

[26] AFAD, “12 Kasım 1999 Düzce Depremi” [Çevrimiçi]. Erişim Adresi: https://deprem.afad.gov.tr/tarihteBuAy?id=61 Erişim Tarihi: 22.05.2019. 